\section{S59 USING VENOUS BLOOD GAS ANALYSIS IN THE MANAGEMENT OF COPD EXACERBATIONS; A PROSPECTIVE COHORT STUDY}

${ }^{1} \mathrm{DE}$ Shaw, ${ }^{2} \mathrm{AM}$ Kelly, ${ }^{3} \mathrm{G}$ Housley, ${ }^{1} \mathrm{G}$ Hearson, ${ }^{1} \mathrm{C}$ Reynolds, ${ }^{1} \mathrm{TW}$ Harrison, ${ }^{4} \mathrm{TM}$ McKeever. ${ }^{1}$ Division of Respiratory Medicine, University of Nottingham, Nottingham, UK; ${ }^{2}$ Joseph Epstein Centre for Emergency Medicine Research, Victoria, Australia; ${ }^{3}$ East Midlands Academic Health Sciences Network, Nottingham, UK; ${ }^{4}$ Division of Epidemiology, University of Nottingham, Nottingham, UK

\subsection{6/thoraxjnl-2015-207770.65}

Introduction COPD exacerbations are a common cause of emergency hospital admission in the UK, with an estimated 94,000 per year. Identifying hypercapnic respiratory failure is crucial. Guidelines recommend obtaining arterial blood samples but these are more difficult to obtain than venous samples. Furthermore, administration of local anaesthetic prior to arterial sampling is seldom used. We assessed whether blood gas values derived from venous samples could replace arterial at initial assessment.

Methods Patients treated for a COPD exacerbation had paired arterial and venous samples taken. Bland Altman analyses were performed to assess agreement between arterial and venous $\mathrm{pH}, \mathrm{PCO}_{2}$ and $\mathrm{HCO}_{3}^{-}$, and between $\mathrm{SpO}_{2}$ and $\mathrm{SaO}_{2}$. The number of attempts and pain scores for each sample were measured.

Results 234 patients had paired arterial and venous samples. There was good agreement between arterial and venous measures of $\mathrm{pH}$ and $\mathrm{HCO}_{3}{ }^{-}$(mean difference 0.03 and -0.04 , limits of agreement -0.54 to 0.11 , and -2.90 to 2.82), and between $\mathrm{SaO}_{2}$ and $\mathrm{SpO}_{2}$ (in patients with a $\mathrm{SpO}_{2}$ of greater than $80 \%)$.

We calculated the sensitivity and specificity of a VBG pH and $\mathrm{HCO}_{3}{ }^{-}$to correctly identify an arterial $\mathrm{pH}$ of $\geq 7.35$, and an arterial $\mathrm{HCO}_{3}{ }^{-}$of $\geq 21$, as well as a $\mathrm{SpO}_{2}$ to identify a $\mathrm{SaO}_{2}$ of $\geq 92 \%$. A venous $\mathrm{pH}$ of 7.34, a venous $\mathrm{HCO}_{3}{ }^{-}$of 21.45 and a $\mathrm{SpO}_{2}$ of 91.5 would have correctly classified $87 \%$ (95\% CI $82 \%$ to $91 \%$ ), $97 \%$ (95\% CI $93 \%$ to $98 \%$ ), and $71 \%$ (95\% CI $65 \%$ to $77 \%$ ), of patients respectively. $96 \%$ of patients with an ABG $\mathrm{pH}$ of $\geq 7.35$ also had a VBG $\mathrm{pH}$ of $\geq 7.35$.

Arterial sampling took more attempts and was more painful than venous (mean pain score 4 (IQR 2-5) and 1 (IQR 0-2), p $<0.001)$.

\begin{tabular}{|c|c|c|c|c|c|}
\hline & $\begin{array}{l}\text { ABG (Mean) } \\
\text { (SD) }\end{array}$ & $\begin{array}{l}\text { VBG } \\
\text { (Mean) } \\
\text { (SD) }\end{array}$ & $\begin{array}{l}\text { Mean Difference } \\
\text { (ABG- VBG) } \\
(95 \% \mathrm{Cl})\end{array}$ & $\begin{array}{l}95 \% \text { Limits } \\
\text { of } \\
\text { agreement }\end{array}$ & $\mathrm{N}$ \\
\hline $\mathrm{pH}$ & $\begin{array}{l}7.40 \\
(0.09)\end{array}$ & $\begin{array}{l}7.37 \\
(0.08)\end{array}$ & $\begin{array}{l}0.03 \\
(0.02 \text { to } 0.04)\end{array}$ & -0.54 to 0.11 & 234 \\
\hline $\mathrm{HCO}_{3}{ }^{-}(\mathrm{mEq} / \mathrm{L})$ & $\begin{array}{l}29.7 \\
(6.3)\end{array}$ & $\begin{array}{l}29.7 \\
(6.4)\end{array}$ & $\begin{array}{l}-0.04 \\
(-0.22 \text { to } 0.15)\end{array}$ & -2.90 to 2.82 & 232 \\
\hline $\mathrm{pCO}_{2}(\mathrm{kPa})$ & $\begin{array}{l}6.89 \\
(2.40)\end{array}$ & $\begin{array}{l}7.63 \\
(2.41)\end{array}$ & $\begin{array}{l}1.93 \\
\text { (1.58 to } 2.28)\end{array}$ & -3.38 to 7.24 & 225 \\
\hline
\end{tabular}

Abstract $\mathrm{S} 59$ Table 2 Agreement between $\mathrm{SaO}_{2}$ and $\mathrm{SpO}_{2}$

\begin{tabular}{llllll}
\hline & $\begin{array}{l}\mathrm{SaO}_{2} \\
(\mathrm{Mean}) \\
(\mathrm{SD})\end{array}$ & $\begin{array}{l}\mathrm{SpO}_{2} \\
(\mathrm{Mean})\end{array}$ & $\begin{array}{l}\text { Mean Difference } \\
\left(\mathrm{SaO}_{2}-\mathrm{SpO}_{2}\right)\end{array}$ & $\begin{array}{l}\text { 95\% Limits of } \\
\text { agreement }\end{array}$ & $\mathrm{N}$ \\
\hline $\begin{array}{l}(95 \% \mathrm{Cl}) \\
\text { Oxygen }\end{array}$ & 91.2 & 91.0 & -0.17 & -11.12 to 10.78 & 224 \\
percentage & $(6.0)$ & $(4.0)$ & $(\mathrm{Cl}-0.89$ to 0.56$)$ & & \\
saturation* & & & & & \\
\hline *in patients with $\mathrm{SpO}_{2}>80 \%$.
\end{tabular}

Conclusion Arterial sampling is more difficult and painful than venous sampling. There is good agreement between $\mathrm{pH}$ and $\mathrm{HCO}_{3}{ }^{-}$values derived from venous and arterial blood, and between pulse oximetry and arterial blood gas oxygen saturations. This could allow the initial assessment of COPD exacerbations to be based on venous blood gas analysis and pulse oximetry, simplifying the care pathway and improving the patient experience.

\section{S60 EFFICACY AND SAFETY OF ACLIDINIUM/FORMOTEROL FIXED-DOSE COMBINATION IN PATIENTS WITH COPD, STRATIFIED BY ICS USE}

${ }^{1} \mathrm{D}$ Singh, ${ }^{2} \mathrm{~A}$ D'Urzo, ${ }^{3} \mathrm{E}$ Garcia Gil. ${ }^{1}$ Medicines Evaluation Unit Ltd, University of Manchester, Manchester, UK; ${ }^{2}$ Department of Family and Community Medicine, Faculty of Medicine, University of Toronto, Toronto, Canada; ${ }^{3}$ AstraZeneca PLC, Barcelona, Spain

\subsection{6/thoraxjnl-2015-207770.66}

Introduction and objectives This was a secondary analysis, stratified by concomitant inhaled corticosteroid (ICS) use, based on pooled data from ACLIFORM (NCT01462942) and AUGMENT (NCT01437397), two Phase III, 24-week, randomised, double-blind studies of twice-daily aclidinium/formoterol (AB/ $\mathrm{FF}$ ) fixed-dose combination in patients with moderate to severe airflow obstruction.

Methods Patients received twice-daily AB/FF 400/12 $\mu \mathrm{g}, \mathrm{AB} / \mathrm{FF}$ $400 / 6 \mu \mathrm{g}, \mathrm{AB} 400 \mu \mathrm{g}$, FF $12 \mu \mathrm{g}$ or placebo (PBO). Any baseline ICS use was continued throughout. Assessments: change from baseline in 1-hour morning post-dose and morning pre-dose (trough) forced expiratory volume in $1 \mathrm{~s}\left(\mathrm{FEV}_{1}\right)$ at Week 24 and Transition Dyspnoea Index (TDI) score (pre-planned), rate of exacerbations and adverse events (AEs).

Results Analyses included 3398 patients (mean age 63.5 years; $60.5 \%$ male; baseline ICS use range 38.7-40.0\%). In patients using ICS, $\mathrm{AB} / \mathrm{FF} 400 / 12 \mu \mathrm{g}$ improved post-dose $\mathrm{FEV}_{1}$, trough $\mathrm{FEV}_{1}$ (Table 1), and TDI vs PBO by $297 \mathrm{~mL}, 145 \mathrm{~mL}$ and 1.59 units, respectively (all $\mathrm{p}<0.001$ ). In addition, in patients receiving concomitant ICS, $\mathrm{AB} / \mathrm{FF} 400 / 12 \mu \mathrm{g}$ improved post-dose $\mathrm{FEV}_{1}$ and trough $\mathrm{FEV}_{1}$ (Table 1) by $109 \mathrm{~mL}$ and $71 \mathrm{~mL}$, respectively, vs FF alone (both $\mathrm{p}<0.001$ ) and by $151 \mathrm{~mL}$ and $54 \mathrm{~mL}$, respectively, $\mathrm{vs} \mathrm{AB}$ alone ( $\mathrm{p}<0.001$ and $\mathrm{p}<0.05$, respectively). In patients not using ICS, there were improvements with $\mathrm{AB} / \mathrm{FF}$ 400/12 $\mu \mathrm{g}$ in post-dose $\mathrm{FEV}_{1}$, trough $\mathrm{FEV}_{1}$ (Table 1) and TDI of $290 \mathrm{~mL}, 135 \mathrm{~mL}$ and 1.36 units vs PBO, respectively (all p < 0.001). The exacerbation rate was higher in patients using ICS 